\title{
Borrelia burgdorferi sensu lato in Ixodes ricinus ticks collected from migratory birds in Southern Norway
}

\author{
Vivian Kjelland ${ }^{1 *}$, Snorre Stuen ${ }^{2}$, Tone Skarpaas ${ }^{3}$, Audun Slettan ${ }^{1}$
}

\begin{abstract}
Background: Borrelia burgdorferi sensu lato (s.l.) are the causative agent for Lyme borreliosis (LB), the most common tick-borne disease in the northern hemisphere. Birds are considered important in the global dispersal of ticks and tick-borne pathogens through their migration. The present study is the first description of $B$. burgdorferi prevalence and genotypes in lxodes ricinus ticks feeding on birds during spring and autumn migration in Norway.

Methods: 6538 migratory birds were captured and examined for ticks at Lista Bird Observatory during the spring and the autumn migration in 2008. 822 immature I. ricinus ticks were collected from 215 infested birds. Ticks were investigated for infection with $B$. burgdorferi s.l. by real-time PCR amplification of the 165 rRNA gene, and $B$. burgdorferi s.l. were thereafter genotyped by melting curve analysis after real-time PCR amplification of the $h b b$ gene, or by direct sequencing of the PCR amplicon generated from the rrs (16S)-rrl (23S) intergenetic spacer.

Results: $B$. burgdorferi s.l. were detected in $4.4 \%$ of the ticks. The most prevalent B. burgdorferi genospecies identified were B. garinii (77.8\%), followed by B.valaisiana (11.1\%), B. afzelii (8.3\%) and B. burgdorferi sensu stricto (2.8\%).

Conclusion: Infection rate in ticks and genospecies composition were similar in spring and autumn migration, however, the prevalence of ticks on birds was higher during spring migration. The study supports the notion that birds are important in the dispersal of ticks, and that they may be partly responsible for the heterogeneous distribution of B. burgdorferi s.l. in Europe.
\end{abstract}

\section{Background}

The main vector for Borrelia burgdorferi sensu lato (s.l.) in Norway is the tick Ixodes ricinus. This tick is distributed along the coastal areas from Østfold in the south to Nordland in the north. Over the past decades, a remarkable increase in the density of tick populations in many areas of Norway, especially on islands, has been reported [1]. This may be due to factors as climatic changes, increased roe deer abundance and changes in habitat structure [2]. Birds, especially ground feeding species, are at risk of tick infestation, and are considered important in the global dispersal of ticks and tick-borne pathogens through their migration within and between continents [3-5]. In addition to transferring infected

\footnotetext{
* Correspondence: vivian.kjelland@uia.no

'University of Agder, Kristiansand, Norway

Full list of author information is available at the end of the article
}

ticks, some avian species may also transport B. burgdorferi as an active infection [5,6]. Migratory birds have been shown to carry large amounts of ticks to Norway $[7,8]$. It is difficult to determine the place of origin of these ticks, and thereby the B. burgdorferi strains, due to the different origin and migratory route for different bird species, but the dominant direction of migration is from southwest to northeast during spring, and the opposite direction during autumn [9]. Although similar studies have been performed in other Nordic countries $[3,4]$, this is the first description of B. burgdorferi prevalence and genotypes in I. ricinus ticks feeding on birds during spring and autumn migration in Norway.

The aim of this study was to contribute to the knowledge of migratory birds' involvement in the ecology of B. burgdorferi s.l. in Norway. 


\section{Material and methods}

\section{Bird capture and tick collection}

Birds were trapped for ringing at Lista Bird Observatory in Southern Norway $\left(58^{\circ} 06^{\prime} \mathrm{N}\right.$; $\left.06^{\circ} 34^{\prime} \mathrm{E}\right)$ in the periods April - June and July - November 2008, periods that are representative of spring and fall migration. Due to a very high number of birds caught at some days during autumn migration, the Bird Observatory staff reported that the birds were not thoroughly examined for ticks every day. Surveillance of migratory birds by standardised trapping and ringing are the primary tasks for the bird observatory, however as some bird species are resident birds in the area, our material includes migratory as well as resident bird species. The birds were trapped in mist nets at ground level. After capture, the birds were identified to species, and their sex and age were determined if possible. Any ticks found on the head of the birds were removed and placed into plastic vials containing $70 \%$ ethanol. The ticks were stored at $4{ }^{\circ} \mathrm{C}$ until further analysis. All ticks were identified to species according to Hillyard [10]. In addition, host-seeking ticks were sampled by flagging the undergrowth with a flannel cloth. The tick collection was performed during dry weather conditions (sunny/cloudy, no precipitation).

\section{DNA extraction}

DNA was isolated by phenol/chloroform extraction. Briefly, nymphal and larval $I$. ricinus ticks were cleansed in phosphate buffered saline (PBS), then in sterile water, before being lightly dried of at a tissue paper. Nymphs were cut longitudinally in two halves using a sterile blade. The ticks were enzymatic digested overnight at $56^{\circ} \mathrm{C}$ in $180 \mu$ lysis buffer $(\mathrm{NaCl} 0.1 \mathrm{M}$, Tris- $\mathrm{HCl} 0.2 \mathrm{M}, \mathrm{pH} 8.0$ EDTA $0.05 \mathrm{M}$, SDS 0.5\%) and $20 \mu \mathrm{l}$ proteinase $\mathrm{K}(20 \mathrm{mg} / \mathrm{ml})$, followed by extraction using phenol/chloroform [11]. The DNA was precipitated with $1 / 10$ volume NaAc $3 \mathrm{M}, \mathrm{pH} 5.0$ and 2.5 volume absolute ethanol, and resuspended in $200 \mu \mathrm{l}$ $0.5 \times$ TE buffer (Tris $5 \mathrm{mM}$, EDTA $0.5 \mathrm{mM}, \mathrm{pH} 8.0$ ). Purified DNA was stored at $-20^{\circ} \mathrm{C}$.

\section{Detection of B. burgdorferi s.I}

DNA extracts were examined for B. burgdorferi spirochetes by using a real-time PCR assay with probe and primers specific for a section of the 16S rRNA gene [12] (Table 1). Real-time PCR was performed using iCycler/ MyIQ $^{\mathrm{sm}}$ (Bio-Rad, California, USA). Briefly, the $25 \mu \mathrm{l}$ PCR mixture included $1 \mathrm{X}$ ready-to-use reaction mixture (TaqMan Universal PCR Master Mix, Applied Biosystems Inc., New Jersey, USA) containing reaction buffer, Taq DNA polymerase, deoxynucleoside triphosphate and $\mathrm{MgCl}_{2}$. The final concentration of the primers and probe were $1.125 \mu \mathrm{M}$ and $0.25 \mu \mathrm{M}$, respectively. Finally, $5 \mu \mathrm{l}$ of template DNA was added. The PCR conditions were as follows: $50^{\circ} \mathrm{C}$ for $2 \mathrm{~min}$ and $95^{\circ} \mathrm{C}$ for $10 \mathrm{~min}$, followed by 50 cycles of $95^{\circ} \mathrm{C}$ for $15 \mathrm{~s}$ and $63^{\circ} \mathrm{C}$ for $60 \mathrm{~s}$.

\section{Genotyping B. burgdorferi species}

Differentiation of the B. burgdorferi s.l. strains was done by a species-specific, single-run, real-time PCR based on the $h b b$ gene sequence as previously described [13]. Briefly, real-time PCR was performed using iCycler/ $\mathrm{MyIQ}^{\mathrm{TM}}$ (Bio-Rad). The $25 \mu \mathrm{l}$ PCR mixture included $1 \mathrm{X}$ ready-to-use reaction mixture (TaqMan Universal PCR Master Mix). The final concentration of the primers and probe (Table 1) was $0.2 \mu \mathrm{M}$ each. Finally, $5 \mu \mathrm{l}$ of template DNA was added. The PCR conditions were as follows: $95^{\circ} \mathrm{C}$ for $10 \mathrm{~min}$, followed by 55 cycles of $95^{\circ} \mathrm{C}$ for $30 \mathrm{~s}, 50^{\circ} \mathrm{C}$ for $45 \mathrm{~s}$ and $72^{\circ} \mathrm{C}$ for $30 \mathrm{~s}$. The amplification was followed by a melting program, which started with denaturation at $95^{\circ} \mathrm{C}$ for $1 \mathrm{~min}$, annealing at $35^{\circ} \mathrm{C}$ for $1 \mathrm{~min}$, followed by $0.5^{\circ} \mathrm{C}$ temperature increase every 30 $\mathrm{s}$ until $85^{\circ} \mathrm{C}$. During the slow heating process, fluorescence was measured at every $0.5^{\circ} \mathrm{C}$. The melting points of the amplicons generated from the unknown samples and from known B. burgdorferi species were compared for genotyping.

In cases where melting temperature was in a region where a clear identification could not be made, genotyping was done by direct sequencing of the chromosome located $r r s$ (16S)-rrlA (23S) intergenic spacer (IGS) [14]. See Table 1 for sequences for IGS primers. Briefly, the locus was amplified by a nested PCR procedure, comprising 35 cycles for the first reaction (IGS1) and 39 cycles for the second reaction (IGS2). The reaction conditions used were as follows: $95^{\circ} \mathrm{C}$ for $5 \mathrm{~min}, 94^{\circ} \mathrm{C}$ for $30 \mathrm{~s}, 50^{\circ} \mathrm{C}$ for the first reaction and $59^{\circ} \mathrm{C}$ for the second reaction for $30 \mathrm{~s}$, and $74^{\circ} \mathrm{C}$ for $3 \mathrm{~min}$. PCR products were sequenced directly in reverse direction on a 3130 Genetic Analyzer automated capillary sequencer (Applied Biosystems Inc.).

\section{Statistical analyses}

Differences in the prevalence of B. burgdorferi s.l. in the larval and nymphal $I$. ricinus ticks collected during spring and autumn migration, respectively, were examined using $\chi 2$ test. Calculations were performed using SPSS statistical software, version 17 . A probability of $P<0.05$ was regarded as statistically significant.

\section{Results}

\section{Tick infestation of birds}

A total of 6538 birds of 85 species were captured and examined for ticks at Lista Bird Observatory during the spring and the autumn migration in 2008. Only $I$. ricinus ticks were found. 822 ticks were collected from 215 infested birds of 34 species, giving a prevalence of $3.3 \%$ (215 of 6538 birds), a relative intensity of 0.13 tick per 
Table 1 Sequences for probes and primers used in this study

\begin{tabular}{llc}
\hline & Sequence $\left(\mathbf{5}^{\prime} \mathbf{-} \mathbf{3}^{\prime}\right)$ & Reference \\
\hline LB probe & 6FAM-TTCGGTACTAACTTTAGTTAA-MGBNFQ & {$[12]$} \\
LB forward primer & GCTGTAAACGATGCACACTTGGT & {$[12]$} \\
LB reverse primer & GGCGGCACACTTAACACGTTAG & {$[12]$} \\
Hbb probe & FAM-CAATGTCTGACTTAGTAACCTTGGTCTTCTTGA-BHQ1 & {$[13]$} \\
Hbb forward primer & GTAAGGAATTAGTTATGTCTTT & {$[13]$} \\
Hbb reverse primer & TAAGCTCTTCAAAAAAGCATCTA & {$[13]$} \\
IGS 1 forward primer & GTATGTTAGTGAGGGGGTG & {$[14]$} \\
IGS 1 reverse primer & GGATCATAGCTCAGGTGGTAG & {$[14]$} \\
IGS 2 forward primer & AGGGGGTGAAGTCGTAACAAG & {$[14]$} \\
IGS 2 reverse primer & GTCTGATAAACCTGAGGTCGGA & {$[14]$} \\
\hline
\end{tabular}

bird (822 ticks per 6538 birds), and a mean intensity of 3.82 ticks per infested bird ( 822 ticks per 215 birds). The prevalence of infested birds were higher during spring migration compared to autumn migration, with $6.18 \%$ (64 of 1035 birds) and 2.74\% (151 of 5503 birds), respectively. Furthermore, the relative intensity of tick infestation was also higher during spring migration compared to autumn migration, with 0.20 tick per bird (202 ticks per 1035 birds) and 0.11 tick per bird (620 ticks per 5503 birds), respectively. However, the mean intensity of tick infestation was lower during spring migration compared to autumn migration, with 3.2 ticks per infested bird (202 ticks per 64 birds) and 4.1 ticks per infested bird (620 ticks per 151 bird), respectively.

A total of 499 larvae and 323 nymphs were collected. No adult ticks were found. During spring migration, 53 larvae and 149 nymphs were collected (Table 2), whereas during autumn migration, 446 larvae and 174 nymphs were collected (Table 3 ). The bird species most commonly infested by ticks were tree pipit (Anthus trivialis) (36.9\%, 7/19), chaffinch (Fringilla coelebs) (18.8\%, 51/272), whitethroat (Sylvia communis) (16.5\%, 20/121), dunnock (Prunella modularis) $(15.6 \%, 5 / 32)$, lesser whitethroat (Sylvia curruca) $(9.4 \%, 3 / 32)$, blackbird (Turdus merula) $(9.2 \%, 22 / 238)$, song thrush (Turdus philomelos) $(7.7 \%, 5 / 65)$, European robin (Erithacus rubecula) $(7.1 \%, 29 / 411)$ and fieldfare (Turdus pilaris) $(6.5 \%, 5 / 77)$.

\section{Host-seeking ticks}

Migrating birds may transport ticks over long distances, but tick infestation may also be a result of local tick recruitment. To investigate the potential role of local tick recruitment, host-seeking ticks were collected in the vicinity of the bird observatory. Five hours of flagging yielded only $6 \mathrm{I}$. ricinus ticks in areas within $0.5 \mathrm{~km}$ from the bird observatory. However, flagging of sites approximately $4 \mathrm{~km}$ and $13 \mathrm{~km}$ from the observatory were performed in the same period, and yielded 428 (173 nymphs and 255 larvae) and 298 (5 adults,
154 nymphs, 140 larvae) ticks per hour of flagging, respectively. $I$. ricinus ticks collected at the site $13 \mathrm{~km}$ from the observatory were examined for B. burgdorferi s.l., and the spirochetes were detected in $24.1 \%$ of nymphal and $16.7 \%$ of adult ticks [13].

\section{B. burgdorferi s.l. infection of ticks and genospecies identification}

B. burgdorferi s.l. were detected in $4.4 \%$ of the ticks. In ticks collected during spring migration, B. burgdorferi s.l. were detected in $5.4 \%$ of nymphal ticks (Table 2), whereas in ticks collected during autumn migration, the spirochetes were detected in $3.4 \%$ of larvae and $7.5 \%$ of nymphs (Table 3). The differences in B. burgdorferi s.l. prevalence in larva and nymphs were not statistically significant between spring and autumn migration. B. garinii was detected in $77.8 \%$, B. valaisiana in $11.1 \%$, B. afzelii in $8.3 \%$ and B. burgdorferi sensu stricto (s.s.) in $2.8 \%$ of the ticks (Table 4 ). Mixed infections with more than one genospecies were not detected in any ticks.

\section{Discussion}

During spring and autumn migration 2008, 6538 birds were examined for tick infestation at Lista Bird Observatory in Southern Norway, and 822 immature I. ricinus were collected from 215 birds. Large variations were found in the contributions of the different bird species to the number of ticks collected. Ticks were found on 34 of the 85 bird species examined. The bird species most commonly infested by ticks were Turdus spp., Anthus trivialis, Fringilla coelebs, Sylvia spp., Prunella modularis and Erithacus rubecula, consistent with previous Norwegian studies $[7,8,15,16]$. These avian species are ground-feeding, which puts them at risk of tick infestation.

The prevalence of ticks on the birds was higher during spring migration compared to autumn migration, with $6.2 \%$ and $2.7 \%$ of the birds infested, respectively. This may be explained by different tick activity during spring and autumn migration and/or by different tick population 
Table 2 Tick infestation of birds and B. burgdorferi s.l. prevalence in I. ricinus, spring 2008

\begin{tabular}{|c|c|c|c|c|c|c|}
\hline Bird species & $\begin{array}{l}\text { No. } \\
\text { birds }\end{array}$ & $\begin{array}{l}\text { No. } \\
\text { ticks }\end{array}$ & $\begin{array}{l}\text { No. (\%) birds } \\
\text { infested }\end{array}$ & $\begin{array}{l}\text { Mean no. ticks per } \\
\text { infested bird }\end{array}$ & $\begin{array}{l}\text { Borrelia infected larvae/no. } \\
\text { larvae examined }\end{array}$ & $\begin{array}{c}\text { Borrelia infected nymphs/no. } \\
\text { nymphs examined }\end{array}$ \\
\hline \multicolumn{7}{|l|}{ Migrating birds } \\
\hline Acrocephalus arundinaceus & 1 & 1 & $1(100)$ & 1 & & $0 / 1$ \\
\hline Acrocephalus palustris & 5 & 1 & $1(20)$ & 1 & & $0 / 1$ \\
\hline Acrocephalus scirpaceus & 3 & 1 & $1(33.3)$ & 1 & & $0 / 1$ \\
\hline Sylvia borin & 17 & 1 & $1(5.9)$ & 1 & & $0 / 1$ \\
\hline Sylvia communis & 28 & 5 & $3(10.7)$ & 1.7 & $0 / 1$ & $0 / 4$ \\
\hline Luscinia svecica & 1 & 1 & $1(100)$ & 1 & $0 / 1$ & \\
\hline Carduelis cannabina & 19 & 1 & $1(5.3)$ & 1 & & $0 / 1$ \\
\hline Carduelis cabaret & 1 & 1 & $1(100)$ & 1 & $0 / 1$ & \\
\hline Carpodacus erythrinus & 4 & 1 & $1(25)$ & 1 & & $0 / 1$ \\
\hline Coccothraustes coccothraustes & 1 & 2 & $1(100)$ & 2 & & $0 / 2$ \\
\hline Phylloscopus collybita* & 65 & 1 & $1(1.5)$ & 1 & & $0 / 1$ \\
\hline Sylvia atricapilla* & 43 & 1 & $1(2.3)$ & 1 & & $0 / 1$ \\
\hline Erithacus rubecula* & 232 & 49 & $24(10.3)$ & 2 & $0 / 27$ & $1 / 22$ \\
\hline Turdus iliacus* & 4 & 8 & $1(25)$ & 8 & $0 / 1$ & $2 / 7$ \\
\hline Turdus merula* & 77 & 83 & $12(15.6)$ & 6.9 & $0 / 14$ & $2 / 69$ \\
\hline Turdus pilaris* & 29 & 4 & $3(10.3)$ & 1.3 & & $1 / 4$ \\
\hline Turdus philomelos* & 17 & 14 & $2(11.8)$ & 7 & $0 / 3$ & $0 / 11$ \\
\hline Fringilla coelebs* & 14 & 2 & $1(7.1)$ & 2 & $0 / 1$ & $0 / 1$ \\
\hline Prunella modularis* & 32 & 23 & $5(15.6)$ & 4.6 & $0 / 3$ & $2 / 20$ \\
\hline Sturnus vulgaris* & 16 & 1 & $1(6.3)$ & 1 & $0 / 1$ & \\
\hline \multicolumn{7}{|l|}{ Resident birds } \\
\hline Carduelis carduelis & 5 & 1 & $1(20)$ & 1 & & $0 / 1$ \\
\hline Total & 614 & 202 & $64(10.4)$ & 3.2 & $0 / 53$ & $8 / 149$ \\
\hline
\end{tabular}

Migrating and resident birds are defined according to Fonstad et al. [9]. Only bird species with at least one tick infested individual are included in the table. *Migrating birds, but some individuals may overwinter

densities along the birds' migration routes in to Norway (spring) compared to in their Norwegian breeding grounds (autumn). However, it is possible that the observed difference is due to the much higher number of birds caught during autumn migration compared to spring migration (5503 and 1135 birds, respectively), which left less time for the bird observatory staff to examine each bird for ticks. However, the mean intensity of tick infestation was higher during autumn migration compared to spring migration, with 4.1 and 3.2 ticks per infested bird, respectively. The reason for this is unknown.

Few ticks were found in the immediate distance $(<0.5 \mathrm{~km})$ from the bird observatory, however, high I. ricinus densities were found in other sites in the region, and local tick recruitment cannot be excluded. Future studies should investigate this, for example by studying genetic variation in $I$. ricinus ticks along migratory routes as previously described [17].

The prevalence of $B$. burgdorferi in ticks collected from birds was $4.4 \%$ (4.0\% and $4.5 \%$ in ticks collected during spring and autumn migration, respectively). In ticks collected during spring migration, B. burgdorferi s.l. were detected in $5.4 \%$ of nymphal ticks, whereas in ticks collected during autumn migration, the spirochetes were detected in $3.4 \%$ of larvae and $7.5 \%$ of nymphs, however, these differences were not statistically significant. The most prevalent genospecies were B. garinii $(77.8 \%)$, followed by B. valaisiana (11.1\%), B. afzelii (8.3\%) and B. burgdorferi s.s. (2.8\%). Other Nordic studies have reported findings of similar infection rate and genospecies composition in ticks collected from migrating birds [3,4]. B. burgdorferi genospecies composition in host-seeking ticks in Southern Norway was described in a previous study [13]. Although local variations were observed, the overall prevalence of $B$. burgdorferi s.l. in I. ricinus was $22.3 \%$, and the general pattern was a dominance of B. afzelii, followed by B. garinii, B. burgdorferi s.s, and B. valaisiana. The low prevalence of $B$. burgdorferi s.l. in ticks collected from birds compared to host-seeking ticks may be explained by the observed differences in sensitivity to host serum among the B. burgdorferi s.l. strains. During feeding, ticks take up host-derived molecules as complement and other blood components. It has been proposed that the genospecies $B$. afzelii is sensitive to avian complement, and that these spirochetes are eliminated in the tick midgut, whereas $B$. garinii survives such a blood meal and can be transmitted to the host [18]. Comparison with present finding of genospecies composition in ticks feeding 
Table 3 Tick infestation of birds and B. burgdorferi s.I. prevalence in I. ricinus, autumn 2008

\begin{tabular}{|c|c|c|c|c|c|c|}
\hline Bird species & $\begin{array}{l}\text { No. } \\
\text { birds }\end{array}$ & $\begin{array}{l}\text { No. } \\
\text { ticks }\end{array}$ & $\begin{array}{l}\text { No. (\%) birds } \\
\text { infested }\end{array}$ & $\begin{array}{l}\text { Mean no. ticks per } \\
\text { infested bird }\end{array}$ & $\begin{array}{c}\text { Borrelia infected larvae/no. } \\
\text { larvae examined }\end{array}$ & $\begin{array}{c}\text { Borrelia infected nymphs/no. } \\
\text { nymphs examined }\end{array}$ \\
\hline \multicolumn{7}{|l|}{ Migrating birds } \\
\hline Acrocephalus scirpaceus & 5 & 1 & $1(20.0)$ & 1 & $0 / 1$ & \\
\hline Phylloscopus trochilus & 440 & 44 & $24(5.5)$ & 1.8 & $0 / 21$ & $1 / 23$ \\
\hline Sylvia curruca & 32 & 4 & $3(9.4)$ & 1.3 & $0 / 3$ & $0 / 1$ \\
\hline Sylvia communis & 93 & 49 & $17(18.3)$ & 2.9 & $1 / 31$ & $0 / 18$ \\
\hline Motacilla flava & 3 & 1 & $1(33.3)$ & 1 & & $0 / 1$ \\
\hline Oenanthe oenanthe & 99 & 1 & $1(1.0)$ & 1 & & $0 / 1$ \\
\hline Carduelis cabaret & 8 & 4 & $2(25)$ & 2 & $0 / 2$ & $0 / 2$ \\
\hline Carduelis cannabina & 41 & 1 & $1(2.4)$ & 1 & $0 / 1$ & \\
\hline Anthus trivialis & 19 & 18 & $7(36.9)$ & 2.6 & $0 / 8$ & $1 / 10$ \\
\hline Sylvia atricapilla* & 135 & 15 & $6(4.4)$ & 2.5 & $0 / 10$ & $0 / 5$ \\
\hline Erithacus rubecula* & 179 & 14 & $5(2.8)$ & 2.8 & $0 / 10$ & $0 / 4$ \\
\hline Turdus iliacus* & 64 & 16 & $2(3.1)$ & 8 & $3 / 4$ & $7 / 12$ \\
\hline Turdus pilaris* & 48 & 7 & $2(4.2)$ & 3.5 & & $0 / 7$ \\
\hline Turdus philomelos* & 48 & 17 & $3(6.3)$ & 5.7 & $0 / 9$ & $0 / 8$ \\
\hline Turdus merula* & 161 & 44 & $10(6.2)$ & 4.4 & $3 / 12$ & $2 / 32$ \\
\hline Emberiza schoeniclus* & 26 & 3 & $2(7.7)$ & 1.5 & $0 / 1$ & $0 / 2$ \\
\hline Fringilla coelebs* & 258 & 361 & $50(19.4)$ & 7.2 & $7 / 322$ & $2 / 39$ \\
\hline Fringilla montifringilla* & 48 & 3 & $1(2.1)$ & 3 & $0 / 2$ & $0 / 1$ \\
\hline Anthus pratensis* & 59 & 2 & $2(3.4)$ & 1 & $0 / 1$ & $0 / 1$ \\
\hline \multicolumn{7}{|l|}{ Resident birds } \\
\hline Cyanistes caeruleus & 1325 & 6 & $4(0.3)$ & 1.5 & $0 / 1$ & $0 / 5$ \\
\hline Lophophanes cristatus & 52 & 1 & $1(1.9)$ & 1 & & $0 / 1$ \\
\hline Parus major & 147 & 1 & $1(0.7)$ & 1 & $0 / 1$ & \\
\hline Carduelis chloris & 99 & 1 & $1(1.0)$ & 1 & $0 / 1$ & \\
\hline Troglodytes troglodytes & 150 & 6 & $4(2.7)$ & 1.5 & $1 / 5$ & $0 / 1$ \\
\hline Total & 3539 & 620 & $151(4.3)$ & 4.1 & $15 / 446$ & $13 / 174$ \\
\hline
\end{tabular}

Migrating and resident birds are defined according to Fonstad et al. [9]. Only bird species with at least one tick infested individual are included in the table. *Migrating birds, but some individuals may overwinter

Table 4 B. burgdorferi s.l. genotypes in I. ricinus ticks collected from birds, 2008

\begin{tabular}{|c|c|c|c|c|c|c|c|c|}
\hline \multirow[b]{2}{*}{ Bird species } & \multirow[b]{2}{*}{$\begin{array}{l}\text { No. birds with infected } \\
\text { ticks/no. birds infested }\end{array}$} & \multicolumn{3}{|c|}{ Borrelia species identified in larvae } & \multicolumn{4}{|c|}{ Borrelia species identified in nymphs } \\
\hline & & $\mathrm{Bg}$ & Bv & $\mathrm{Ba}$ & $\mathrm{Bg}$ & Bv & $\mathrm{Ba}$ & Bbss \\
\hline \multicolumn{9}{|l|}{ Migrating birds } \\
\hline Phylloscopus trochilus & $1(24)$ & & & & & & & 1 \\
\hline Sylvia communis & $1(20)$ & 1 & & & & & & \\
\hline Anthus trivialis & $1(7)$ & & & & 1 & & & \\
\hline Erithacus rubecula* & $1(29)$ & & & & & & 1 & \\
\hline Turdus iliacus* & $2(3)$ & 3 & & & 9 & & & \\
\hline Turdus merula* & $4(22)$ & 1 & 2 & & 2 & 2 & & \\
\hline Turdus pilaris* & $1(5)$ & & & & 1 & & & \\
\hline Fringilla coelebs* & $8(51)$ & 7 & & & 2 & & & \\
\hline Prunella modularis* & $2(5)$ & & & & 1 & & 1 & \\
\hline \multicolumn{9}{|l|}{ Resident birds } \\
\hline Troglodytes troglodytes & $1(4)$ & & & 1 & & & & \\
\hline Total & $22(170)$ & 12 & 2 & 1 & 16 & 2 & 2 & 1 \\
\hline
\end{tabular}

Migrating and resident birds are defined according to Fonstad et al. [9]. Only bird species carrying B. burgdorferi s.l. infected tick(s) are included in the table. *Migrating birds, but some individuals may overwinter 
on birds support the notion of a genospecies specific association between birds and B. garinii, and an elimination of B. afzelii infections.

B. burgdorferi infection was detected in $3.8 \%$ of larvae carried by the avian species redwing (Turdus iliacus), blackbird (Turdus merula), chaffinch (Fringilla coelebs), whitethroat (Sylvia communis) and winter wren (Troglodytes troglodytes). Larval infection does not necessarily imply host reservoir competence, as infection may also arise from transovarial transmission or from co-infection [19]. However, previous studies have demonstrated Turdus spp. as reservoir hosts for B. garinii and B. valaisiana $[6,20,21]$, supporting the possibility of the bird as a source of infection. However, further studies are necessary to determine the potential reservoir capacity of chaffinch, whitethroat and winter wren.

As previously described, the birds were not thoroughly examined for ticks every day during autumn migration. Furthermore, our material includes migratory as well as resident bird species. These factors may have influenced findings in the present study, and future studies should attempt to avoid these potentially confounding factors.

\section{Conclusion}

These data support the notion that birds may be partly responsible for the heterogenous distribution of B. burgdorferi s.l. in Europe. Further studies are necessary to evaluate the impact of different bird species on Lyme borreliosis ecology. Ticks may be infected by a wide range of important pathogens, including tick-borne encephalitis virus (TBEV) and Anaplasma phagocytophi$l u m$, and future studies should also include investigation of the birds' role in the ecology of these pathogens.

\section{Acknowledgements}

This work was supported by The Competence Development Fund of Southern Norway and The Norwegian Ministry of Education and Research. We thank the staff at Lista Bird Observatory for collecting ticks from birds. We are also grateful to Sven Bergström and his group at the Departement of Molecular biology, Umeå University, and Eva Ruzic-Sabljic and her group at the Institute of Microbiology and Immunology, Medical faculty, University of Ljubljana, for their great hospitality, and for providing Borrelia strains.

\section{Author details}

${ }^{1}$ University of Agder, Kristiansand, Norway. ${ }^{2}$ National Veterinary Institute, Sandnes, Norway. ${ }^{3}$ Sørlandet Hospital Health Enterprise (SSHF), Kristiansand, Norway.

\section{Authors' contributions \\ VK, SS, TS and AS designed the study. VK carried out the experiments. VK and SS drafted the manuscript. AS provided technical assistance. All authors read and approved the final manuscript.}

\section{Competing interests}

The authors declare that they have no competing interests.
References

1. Mehl R: The distribution and host relations of Norwegian ticks (Acari, Ixodides). Fauna Norvegica 1983, 30:46-50.

2. Randolph SE: Evidence that climate change has caused 'emergence' of tick-borne diseases in Europe? Int J Med Microbiol 2004, 293(Suppl 37):5-15.

3. Olsen B, Jaenson TGT, Bergstrom S: Prevalence of Borrelia burgdorferi sensu lato-infected ticks on migrating birds. Appl Environ Microbiol 1995, 61(8):3082-7.

4. Comstedt P, Bergstrom S, Olsen B, Garpmo U, Marjavaara L, Mejlon H, Barbour AG, Bunikis J: Migratory passerine birds as reservoirs of Lyme borreliosis in Europe. Emerg Infect Dis 2006, 12(7):1087-95.

5. Olsen B, Duffy DC, Jaenson TGT, Gylfe A, Bonnedahl J, Bergstrom S: Transhemispheric exchange of Lyme disease spirochetes by seabirds. J Clin Microbiol 1995, 33(12):3270-4.

6. Gylfe $\AA$, Bergstrom S, Lundstrom J, Olsen B: Reactivation of Borrelia infection in birds. Nature 2000, 403(6771):724-5.

7. Hasle G, Bjune G, Edvardsen E, Jakobsen C, Linnehol B, Røer JE, Mehl R, Røed KH, Pedersen J, Leinaas HP: Transport of ticks by migratory passerine birds to Norway. J Parasitol 2009, 95(6):1342-1351.

8. Mehl R, Michaelsen J, Lid G: Ticks (Acari, Ixodides) on migratory birds in Norway. Fauna Norvegica 1984, 31:46-58.

9. Fonstad T, Gensbøl B, Günther M: Aschehougs Fuglebok Oslo, Norway: H. Aschehoug \& Co; 2008

10. Hillyard PD: Ticks of North-West Europe. In Synopsis of the British Fauna (New Series). Volume 52. Edited by: Barnes RSK, Chrothers JH. Field Studies Council, Shrewsbury; 1996.

11. Halos L, Jamal T, Vial L, Maillard R, Suau A, Le Menach A, Boulouis HJ, Vayssier-Taussat M: Determination of an efficient and reliable method for DNA extraction from ticks. Vet Res 2004, 35(6):709-13.

12. Tsao Jl, Wootton JT, Bunikis J, Luna MG, Fish D, Barbour AG: An ecological approach to preventing human infection: vaccinating wild mouse reservoirs intervenes in the Lyme disease cycle. Proc Natl Acad Sci USA 2004, 101(52):18159-64.

13. Kjelland V, Stuen S, Skarpaas T, Slettan A: Prevalence and Genotypes of Borrelia burgdorferi sensu lato Infection in Ixodes ricinus ticks in Southern Norway. Scand J Infect Dis 2010, 42(8):579-85.

14. Bunikis J, Garpmo U, Tsao J, Berglund J, Fish D, Barbour AG: Sequence typing reveals extensive strain diversity of the Lyme borreliosis agents Borrelia burgdorferi in North America and Borrelia afzelii in Europe. Microbiology 2004, 150(6):1741-55

15. Paulauskas A, Radzijevskaja J, Rosef O: Anaplasma in ticks feeding on migrating birds and questing ticks in Lithuania and Norway. Clin Microbiol Infect 2009, 15(Suppl 1).

16. Paulauskas A, Rosef $O$, Galdikaite E, Radzijevskaja J: Infestation with Ixodes ricinus ticks on migrating passerine birds in Lithuania and Norway. Acta Biol Univ Daugavp 2009, 9(1):1-6.

17. Paulauskas A, Radzijevskaja J, Rosef O, Turcinaviciene J, Ambrasiene D, Makareviciute D: Genetic variation of ticks (Ixodes ricinus L.) in the Lithuanian and Norwegian populations. Exp Appl Acarol 2006, 40(34):259-70.

18. Kurtenbach K, De Michelis S, Etti S, Schafer SM, Sewell HS, Brade V, Kraiczy P: Host association of Borrelia burgdorferi sensu lato-the key role of host complement. Trends Microbiol 2002, 10(2):74-9.

19. Randolph SE, Gern L, Nuttall PA: Co-feeding ticks: Epidemiological significance for tick-borne pathogen transmission. Parasitol Today 1996, 12(12):472-9.

20. Taragel'ova V, Koci J, Hanincova K, Kurtenbach K, Derdakova M, Ogden NH, Literak I, Kocianova E, Labuda M: Blackbirds and song thrushes constitute a key reservoir of Borrelia garinii, the causative agent of borreliosis in Central Europe. Appl Environ Microbiol 2008, 74(4):1289-93.

21. Humair PF, Postic D, Wallich R, Gern L: An avian reservoir (Turdus merula) of the Lyme borreliosis spirochetes. Zentralb/ Bakteriol 1998, 287(4):521-38.

doi:10.1186/1751-0147-52-59

Cite this article as: Kjelland et al:: Borrelia burgdorferi sensu lato in Ixodes ricinus ticks collected from migratory birds in Southern Norway. Acta Veterinaria Scandinavica 2010 52:59. 